2 П. А. Булдыгин, М. Д. Фаткуллина Оптимизация государственных закупок. Повышение качества поставляемых товаров и услуг // Экономика и бизнес: теория и практика. 2019. №4-2.

3 Мария Михайловна Исаичева Перспективы декриминализации сферы осуществления закупок для государственных и муниципальных нужд // Закон и право. 2020. №2.

${ }^{4}$ Бехер Вероника Виссарионовна, Лайченкова Наталия Николаевна Информатизация системы закупок для государственных (муниципальных) нужд: организационные и правовые вопросы // ИБР. 2018. №1 (30).

5 Управления закупками и заказами [Электронный ресурс] : учеб. пособие / С.Н. Ревина, П.А. Паулов, Д.В. Борякин. - Самара : Изд-во Самар. гос. экон. ун-та, 2019.

\title{
ACTUAL PROBLEMS OF THE PROCESS OF OPTIMIZATION OF PUBLIC PURCHASES AND ORDERS
}

\author{
(c) 2020 Borodinova Viktoria Vitalievna \\ Student \\ Samara State University of Economics \\ E-mail: borodinova.vikroriya.1999@mail.ru
}

Keywords: public procurement, legislation, optimization, order, contract, budget.

The article examines the issue of reforming the public procurement system and orders. The author of the article analyzes the controversial issues of optimizing the system of public procurement and orders. The question of the relevance of the current mechanism of the regulatory and legal framework is examined, and an assessment is given regarding the changes proposed by the legislator. The research methodology is an analysis of the scientific literature on a given topic, as well as practical experience on a given topic.

УДК 347.9

Код РИНЦ 10.31.41

\section{К ВОПРОСУ О ТРЕБОВАНИЯХ, ПРЕДЪЯВЛЯЕМЫХ К СУДЕБНЫМ РЕШЕНИЯМ}

\author{
(c) 2020 Борченко Ксения Денисовна \\ студент \\ (с) 2020 Лошкарев Андрей Викторович \\ доцент \\ Самарский государственный экономический университет \\ E-mail: ksenniia.borchenko@yandex.ru
}

Ключевые слова: судебное решение, законность, обоснованность, справедливость, целесообразность.

В статье рассматриваются требования к судебному решению, установленные в законодательстве и юридической литературе. Анализируются различные мнения ученых и нормы Гражданскопроцессуального кодекса. 
Судебное решение является важнейшим правоприменительным актом на стадии судебного разбирательства, а именно вынесение такого важного решения должно соответствовать определенным требованиям, установленных законом.

Общие требования содержатся в ст. 195 Гражданско-процессуального кодекса Российской Федерации ${ }^{1}$ (далее - ГПК РФ), где сказано только о законности и обоснованности решения суда. Однако в юридической литературе также содержится перечень других требований, которым должно отвечать судебное решение. Список таких требований не является исчерпывающим.

Следует сказать, что еще в советский период именно этому вопросу в юридической литературе уделялось немало внимания. Так, ученый П.Н. Сергейко полагал, что необходимо выделить такое требование как целесообразность. Особенно такое требование следует применять в делах о разделе имущества2․ С.Г. Ткачева поддерживала такую точку зрения, так как по ее мнению требование целесообразности в судебном решении выражается в выборе наиболее эфффективного решения со стороны суда, где максимально полно будет отражаться смысл закона и цель, которую он преследует. Однако такое мнение нельзя полностью считать правильным. Так, при разрешении дел суд должен применять только нормы права. Из этого можно сделать вывод, что нельзя допускать проявления формализма, либо же произвола, которые можно оправдать требованию целесообразности. Кроме того, в законе не предусмотрено такого основания для изменения или отмены решения, как несоответствие целесообразности решения.

Следующее требование, которое необходимо рассмотреть является требование справедливости. Существует также много споров по поводу этого требования в юридической литературе. А.Т. Боннер считает, что требования законности, обоснованности и справедливости тесно связаны между собой. Однако эти термины определяют разные качественные характеристики судебного решения. В таком случае справедливость будет заключаться в вынесении наиболее оптимального, соответствующего решения в сложившихся обстоятельствах дела 3 .

Ученые Т.Т. Алиев, И.И. Жевак также отмечают, что в настоящее время справедливость является важным требованием судебного решения. Кроме этого необходимо обеспечить также информационный доступ к ним. Так, 22.12.2008 г. был принят Федеральный закон. № 262-Ф3 "Об обеспечении доступа к информации о деятельности судов в Российской Федерации". Принятие этого нормативно-правового акта стало огромным шагом в сторону обеспечения гласности и прозрачности правосудия 4 .

Исходя из вышесказанного, можно сделать вывод, что справедливость судебного решения нельзя рассматривать в качестве требования наряду с требованиями законности и обоснованности. Справедливость судебного решения должна выражаться через правильное применение норм законодательства, что охватывается понятием законности.

Наука выделяет и такие требования, как аргументированность и мотивированность. Аргументированность в любом случае является составной частью для мотивированности любого судебного решения. Однако и здесь есть определенные споры, касающиеся тождественности понятий обоснованность, мотивированность и мотивировочная часть. Важно отметить различие этих понятий, которое состоит в том, что обоснованность выражается в выводах, сделанных судом на основе доказательственной базы ${ }^{5}$. А мотивированность в свою очередь выражается в оценке этих доказательств, наличие в решении ссылок на них, толкование применяемой правовой нормы. Мотивировочная часть в соответствии с нормами законодательства, а именно ст. 198 ГПК РФ должна включать фракти- 
ческие и иные обстоятельства дела, доказательства, выводы суда, законы и иные нормативно-правовые акты, которыми руководствовался суд при принятии решения. Так, значимость мотивировочной части состоит в том, что суд оценивает доказательства и их достоверность, затем анализирует доказательственный материал, после чего объявляет итоги исследования и результаты разбирательства.

Кроме этого, следует отметить, что понятие мотивированности разработано судебной практикой и наукой. В Постановлении Пленума Верховного Суда РФ от 19 декабря 2003 г. № 23 "О судебном решении" мотивированность рассматривается и для анализирования законодательства, и для обоснования судебного решения 6 . Законодатель установил, что суд должен не только перечислить имеющиеся доказательства по делу, но и изложить их содержание. Если суд установил, что представленные материалы, показания свидетелей и иные документы не подтверждают обстоятельства, представленными сторонами, то в судебном решении должно быть мотивированно такое решение.

Именно мотивированность позволяет суду апелляционной, кассационной или надзорной инстанции проверить законность и обоснованность уже вынесенного решения. Следует отметить, что в ГПК РФ не содержится требований относительно мотивированности решения, а в Арбитражном процессуальном Кодексе РФ7 (далее - АПК РФ) такая норма содержится. Так, в п. 6 ст. 185 указано, что в определении должны содержаться мотивы, в соответствии с которыми суд пришел к таким выводам, принял или отклонил доводы лиц, которые участвуют в деле, при этом ссылаясь на законы и иные нормативноправовые акты.

Таким образом, можно сделать вывод, что мотивированность судебного решения выражается в основании принятого решения и других необходимых данных. Мотивированность позволяет понять решение суда, их выводы и причины, по которым суд принял такое решение.

Юридическая литература также содержит такие требования, как полнота, категоричность и безусловность. Судебное решение должно быть исчерпывающим и полным по итогам разрешения всего дела, включать полный ответ на все вопросы и возражения, поступившие от сторон, участвующих в деле8. Кроме этого, судебное решение должно содержать окончательный ответ по поводу возникшего спорного права, а также содержать ответ на все требования, являющихся предметом судебного рассмотрения дела. Также полнота судебного решения выражается и в распределении расходов, устанавливается порядок и способы осуществления права, признанного за одной из сторон. Полнота судебного решения характеризуется разрешением требования истца, разрешением встречного иска и т.д., т.е. суд должен вынести исчерпывающий ответ по отношению к заявленным требованиям и возражениям.

Также стоит отметить, что, как правило, в каждом деле должно быть одно решение. Однако бывает и так, что не все вопросы отражаются в судебном решении или же вообще не рассматриваются заявленные вопросы истцом. В таких случаях законодателем предусмотрен способ исправления неполноты судебного решения. В соответствии со ст. 201 ГПК РФ предусмотрено принятие дополнительного решения суда. Так, суд вправе принять дополнительное решение в случаях, если:

- по требованию, по которому были предоставлены доказательства лицами, участвующими в деле, не было принято решение суда;

- суд, разрешив вопрос о праве, не указал размер присуждаемой суммы, имущество, которое подлежит передаче или обязанность ответчика совершить определенные действия; 
- суд не разрешил вопрос о судебных издержках.

Суд не вправе при принятии дополнительного решения изменить часть судебного решения или разрешить новые вопросы, которые не были рассмотрены в судебном заседании. После принятия дополнительное решение становится неотъемлемой частью основного судебного решения. Оно может быть обжаловано в вышестоящий суд лицами, участвующими в деле, также на определение суда об отказе в принятии дополнительного решения может быть подана частная жалоба.

Таким образом, на основе всего вышесказанного можно сделать вывод, что в соответствии с законодательством главными требованиями являются законность и обоснованность судебного решения. Их выполнение в любом случае является обязательным условием для вынесения решения судом. Следует отметить, что нельзя выдвигать множество требований к решению суда, однако анализ законодательства позволяет сказать, что косвенно законодатель закрепил такие требования, как полнота и определенность (например, в статьях 198, 201, 206, 207 ГПК РФ). Более того, законодатель предусмотрел случаи, когда можно вынести дополнительное решение в случаях, если изначальное решение суда не соответствовало требованиям полноты.

1 Гражданский процессуальный кодекс Российской Федерации от 14.11.2002 N 138-Ф3 (ред. от 02.12.2019) // Система КонсультантПлюс (дата обращения 07.03.2020).

2 Сергейко П.Н. Законность, обоснованность и справедливость судебных актов. Краснодар, 1974. C. 122.

${ }^{3}$ Боннер А.Т. Законность и справедливость в правоприменительной практике // М., 1992. С. 92.

${ }^{4}$ Алиев Т.Т., Жевак И.И. Понятие и виды требований, предъявляемых к решению суда первой инстанции // Современное право. 2012. № 8. С. 107-111.

${ }^{5}$ Савина Ю.Н. Требования, предъявляемые к судебному решению // Юридический аналитический журнал. 2006. № 3-4. С. 180.

6 О судебном решении: Постановление Пленума Верховного Суда РФ от 19.12 .2003 г. № 23 (ред. от 23.06.2015 г.) // Система КонсультантПлюс (дата обращения 09.03.2020).

${ }_{7}^{7}$ Арбитражный процессуальный кодекс Российской Федерации от 24.07.2002 г. № 95-Ф3 (ред. от 02.12.2019) // Система КонсультантПлюс (дата обращения 09.03.2020).

8 Зайганова С.К. Судебные акты в гражданском и арбитражном процессе: теоретические и прикладные проблемы: автореф. дис. ...д-ра юрид. наук. Екатеринбург, 2008. С. 23.

\title{
ON THE ISSUE OF REQUIREMENTS FOR JUDICIAL DECISIONS
}

\author{
(C) 2020 Borchenko Ksenia Denisovna \\ Student \\ (c) 2020 Loshkarev Andrey Viktorovich \\ Associate Professor \\ Samara State University of Economics \\ E-mail: ksenniia.borchenko@yandex.ru
}

Keywords: judicial decision, legality, validity, fairness, expediency.

The article considers the requirements for a court decision established in the legislation and legal literature. Various opinions of scientists are analyzed and norms of the Civil procedure code are analyzed. 